\title{
The Oil Recovery Mechanism of Activated Indigenous Microorganisms
}

\section{by Nutrient Agents}

\author{
G.L. REN ${ }^{1, a}$, J.L. WANG ${ }^{1, b}$, Y.X LI ${ }^{2, c}$, H.M. YUAN ${ }^{1, d}$, J.J. LE ${ }^{3, e}$, J.Y. ZHANG ${ }^{3, f}$, \\ L.L. BAl ${ }^{3, g}$, X.H. $\mathrm{CHEN}^{3, \mathrm{~h}}, \mathrm{H} . \mathrm{ZHANG}^{1, \mathrm{I}}$ \&Y.H. HUANG ${ }^{1, j,{ }^{,}}$ \\ ${ }^{1}$ School of Biotechnology, Daqing Normal University, Daqing, Heilongjiang 163712, China \\ ${ }^{2}$ Institute of Geological Processes, Qingxin Oilfield Company,Ltd., Suihua, Heilongjiang 151413, \\ China
}

${ }^{3}$ Exploration and Development Research Institute, Daqing Oilfield Company,Ltd., Daqing, Heilongjiang 163712, China

arengl272@163.com, ${ }^{b}$ wangjinlong_08@163.com, ${ }^{\mathrm{C}}$ Liyx@petrochina.com.cn, ${ }^{\mathrm{d}} \mathrm{y}$ yuanhm1979@163.co

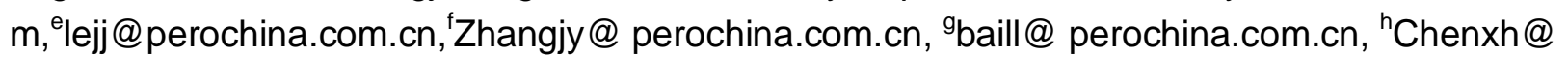
perochina.com.cn, 'xuanlingmu123@sina.com, * corresponding author: 'rengl272@aliyun.com

KEYWORD: Indigenous Microorganisms; Nutrient Agent; Community Structure; Biogas Production

ABSTRACT: In order to achieve a group of desired nutrient agent of indigenous microorganism of oil reservoir after polymer flooding in Daqing oilfield, biogas production experiments, physical simulation experiments and 16S rRNA gene library experiments were carried out. The first and second group of nutrient agents could make biogas pressure reach $0.85 \mathrm{MPa}$ and $1.15 \mathrm{MPa}$ in a high pressure vessel, respectively. The oil recovery efficiency of the first and second group of nutrient agents can be improved by $4.8 \%$ and $3.2 \%$ in physical simulation experiments, respectively. The major bacteria activated by the first activator system were Pseudomonas sp. 72\%, Arcobacter sp. $18 \%$, Thauera sp. $6 \%$. The major bacteria activated by the second activator system were Thauera sp. 65\%, Pseudomonas sp. 18\%, Clostridium sp. 9\%. Methanosaeta sp., Methanolinea sp., Methanobacterium sp. and Methanococcus sp. were the major archaea in oil reservoir after polymer flooding, which were not activated by the two activator systems.

After polymer flooding nearly $35 \%$ of the oil reserves has not been exploited, it is extremely difficult to further tap the potential remaining oil by some conventional techniques in oil reservoirs after polymer flooding ${ }^{[1,2]}$. Many foreign countries such as the United States, Russia and so on, have made lots of field tests of microbial enhanced oil recovery, and achieved some results ${ }^{[3,4]}$. China also carried out some research since the 1960's in some areas, have aslo achieved some results ${ }^{[5,6]}$. Microbial enhanced oil recovery technology as an important reserve technology, the experimental study has been carried out for many years in Daqing oilfield. But microbial enhanced oil recovery technology still stay in the field test stage. According to different microorganisms source, microbial enhanced oil recovery technology mainly includes the endogenous microbial oil recovery and the exogenous microbial oil recovery ${ }^{[7]}$. The endogenous microbial oil recovery refers to use the nutrients activator agents to activate microorganisms and improve productions of acid, biogas, biosurfactants, in order to improve oil recovery ${ }^{[8]}$. It has the advantages of good environmental adaptability, simple technical process, low cost and so on. The key of the technology is the screening tests of nutrients activator agents for specific reservoir environment. Biogas production performance tests, activated microbial numbers and types tests and physical simulation experiments were three important evaluation standards of the nutrient agents' activation effects ${ }^{[9]}$. 
Therefore, in order to test two groups of nutrient agents' activation effects for microorganisms of oil reservoirs after polymer flooding, biogas production experiments, physical simulation experiments and 16S rRNA gene library experiments were carried out. Biogas production experiments test biogas pressure in a high pressure vessel during the activation process. We constructed the $16 \mathrm{~S}$ rRNA gene library to analyse the changes of bacteria and archaea before and after nutrient agents' activation. The oil recovery efficiency of nutrient agents system can be tested in physical simulation experiments. The study of biogas production performance and oil recovery mechanism of activated indigenous microorganisms by nutrient agents offer the reliable basis for the orientation of the endogenous microbial oil recovery.

\section{MATERIALS AND METHODS}

\section{Materials}

The experimental water was collected from the N2-D3-P40 well in the South Two Block of oil reservoirs after polymer flooding in Daqing oilfield, the experimental oil is dewatering crude oil of the N2-D3-P40 well in the South Two Block of oil reservoirs after polymer flooding in Daqing oilfield. Experimental equipments include stainless steel pressure vessel, MyCycler gradient PCR, incubator, physical simulation device, ultra low temperature freezer and so on.

\section{Nutrient agents}

The first group of nutrient agent: molasses $0.6 \%, \mathrm{NaNO}_{3} 0.1 \%, \mathrm{NH}_{4} \mathrm{Cl} 0.1 \%$, yeast powder $0.02 \%$, $\mathrm{KH}_{2} \mathrm{PO}_{4} 0.02 \%, \mathrm{MgSO}_{4} 0.02 \%, \mathrm{~K}_{2} \mathrm{HPO}_{4} 0.01 \%$; the second group of nutrient agent: corn syrup powder $1.0 \%, \mathrm{NaNO}_{3} 0.2 \%,\left(\mathrm{NH}_{4}\right)_{2} \mathrm{HPO}_{4} 0.15 \%, \mathrm{KCl} 0.05 \%, \mathrm{MgSO}_{4} 0.02 \%$ 。

\section{Biogas production tests}

Nutrient agents were dissolved in production water of the N2-D3-P40 well, put it into stainless steel pressure vessel, link pressure gauge to pressure vessel. The microorganisms of production water remained static culture at $45^{\circ} \mathrm{C}$ about 25-30 days, recorded the biogas pressures during different periods.

\section{Physical simulation experiments}

The protocol of physical simulation experiments was described as ${ }^{[10]}$ : (1) pumping vacuum; (2) saturating water; (3) saturating oil; (4) water flooding; (5) polymer flooding; (6) injecting nutrient agents; (7) subsequent water flooding; (8) the evaluation of the oil recovery efficiency.

\section{Construction of 16S rRNA gene libraries}

PCR amplification was performed with universal primers of 16S rRNA gene for bacteria and archaea $^{[12,13]}$; the amplified 16S rDNA fragment was connected with pMD19-T vector (Promega); The ligated products were transformed into E.coli competent cells; Cells (50 $\mu \mathrm{l})$, incubated for 45 min at $37{ }^{\circ} \mathrm{C}$, were spread on LB plates containing ampicillin $(100 \mu \mathrm{g} / \mathrm{ml})$, IPTG $(50 \mathrm{mM})$, and $\mathrm{X}-\mathrm{Gal}(80 \mu \mathrm{g} / \mathrm{ml})$. About one hundred putative clones (white) from each plate were selected to sequence. The 16S rDNA sequences were analysed by GenBank database; the NJ method construction of phylogenetic trees used MEGA 4.1 software $^{[14]}$.

\section{RESULTS AND ANALYSIS}

\section{The biogas production results of nutrient agents}

Biogas production is one of some important mechanisms of the endogenous microbial oil recovery by injecting nutrient agents. The first and second group of nutrient agents could make the biogas pressure reached $0.85 \mathrm{MPa}$ and $1.15 \mathrm{MPa}$ in a high pressure vessel after 9 days, respectively (Figure 1). The biogas pressure's levels of the two systems were kept until 25 days. The results showed the two systems had good performance of the biogas production. 


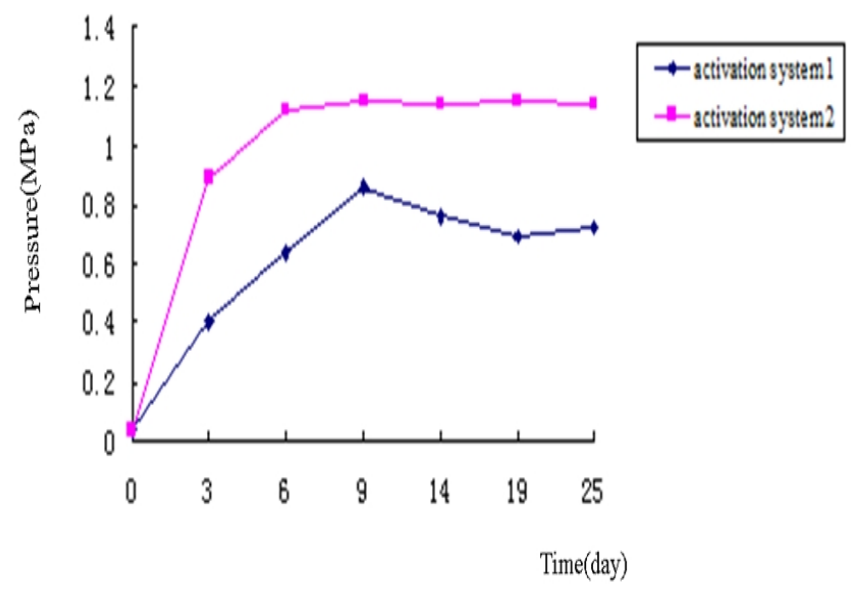

Figure 1. Pressure variation of high pressure vessels during the activation process of indigenous microorganisms

\section{The effects of nutrient activators on microbial community structure}

In order to analyse the activated microbial community by nutrient activators, 16S rDNA gene libraries of indigenous microorganisms were constructed before and after activator agents' activation. DNA sequences of the major dominant bacteria were compared with those in the NCBI database and related sequences are listed in Tables 1, 2 and 3.The major dominant bacteria are Thauera sp. (56\%), Pseudomonas sp. (21\%), uncultured Arcobacter sp. (8\%), Acinetobacter sp. (7\%) and uncultured Bacteroides sp. (5\%) before activation (Table 1). After the first activator agents' activation, the major dominant bacteria are Pseudomonas sp. (72\%), uncultured Arcobacter sp. (18\%) and Thauera sp. (6\%) (Table 2). The major dominant bacteria are Thauera sp. (6\%), Pseudomonas sp. (72\%), uncultured Arcobacter sp. (18\%) and after the second activator agents' activation (Table 3). Phylogenetic trees are shown in Figure 2, 3, 4. These results showed that the activated bacteria by the first group of nutrient agents are Pseudomonas sp. and Arcobacter sp., the activated bacteria by the second group of nutrient agents are Thauera sp., Pseudomonas sp. and uncultured Clostridium sp..

DNA sequences of the major dominant archaea were compared with those in the NCBI database and related sequences are listed in Tables 4, 5, 6. The major dominant bacteria are uncultured Methanosaeta sp. (54\%), uncultured Methanolinea sp. (23\%), Methanobacterium thermaggregans strain (9\%) and Methanococcus sp. (7\%) before activation (Table 4). After the two nutrient agents' activation, the major dominant archaea haven't been basically changed(Table 5, 6). The major dominant archaea are still uncultured Methanosaeta sp., uncultured Methanolinea sp., Methanobacterium thermaggregans strain and Methanococcus sp.. Phylogenetic trees are shown in Figure 5, 6.

\section{The results of Physical simulation experiments}

In order to assess the oil recovery effect of the activating endogenous microorganisms, physical simulation experiments were carried out. The results showed that physical simulation flooding could increase the oil recovery by $3.4 \%$ and $4.8 \%$ after the polymer flooding under the condition of 0.3 PV activator agents, respectively. 


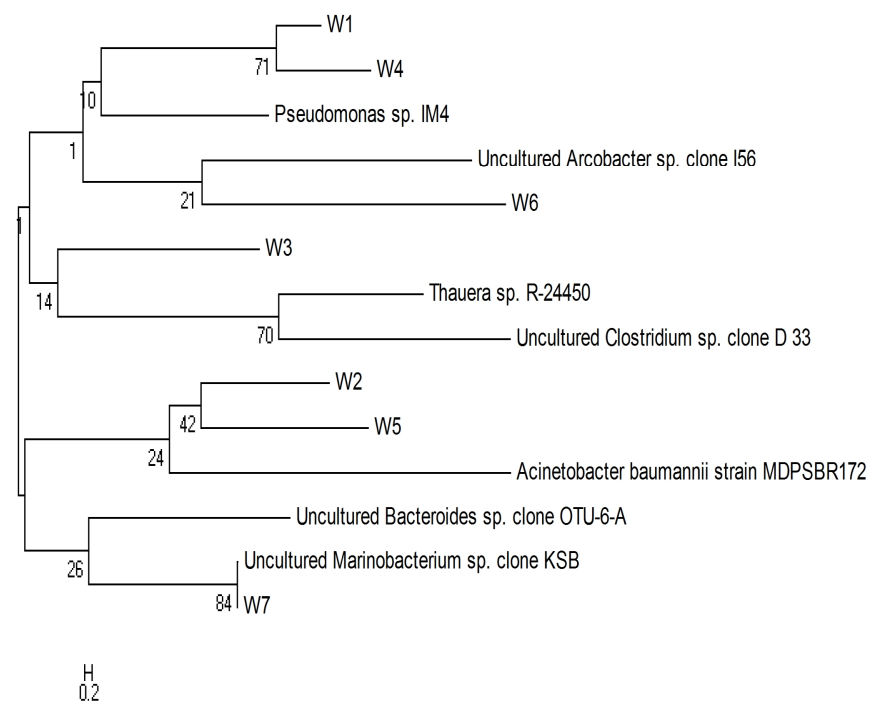

Figure 2. Phylogenetic trees of 16SrDNA gene sequences of bacteria before activation and their most similar sequences of GenBank

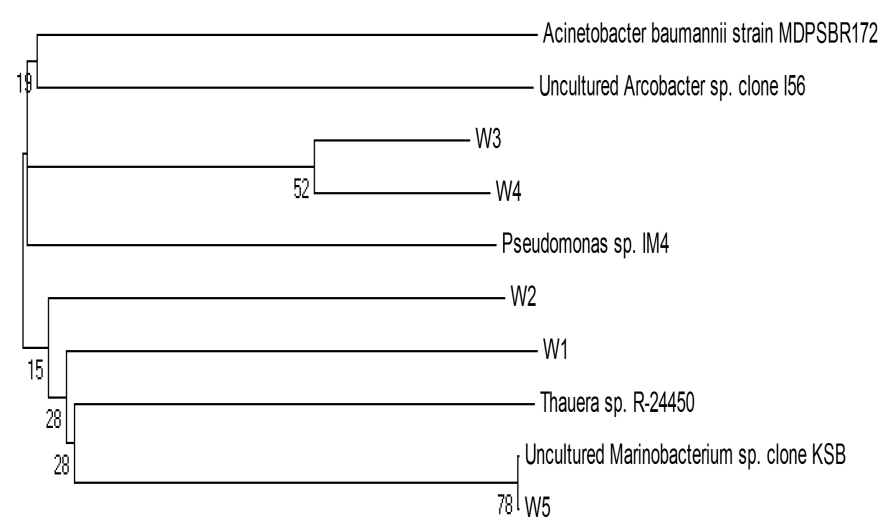

$\vdash_{0.2}$

Figure 3. Phylogenetic trees of 16SrDNA gene sequences of bacteria after the first group of nutrient agents' activation and their most similar sequences of GenBank

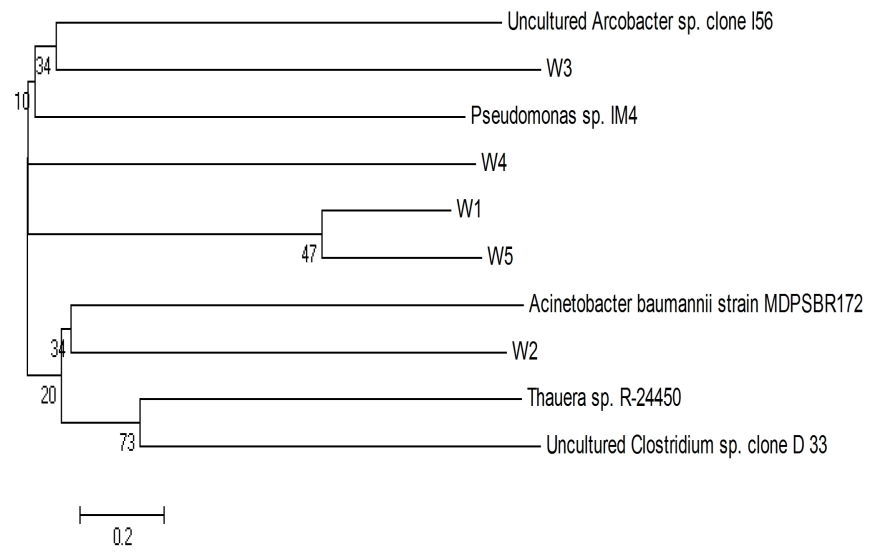

Fig.4 Phylogenetic trees of 16SrDNA gene sequences of bacteria the second group of nutrient agents' activation and their most similar sequences of GenBank 


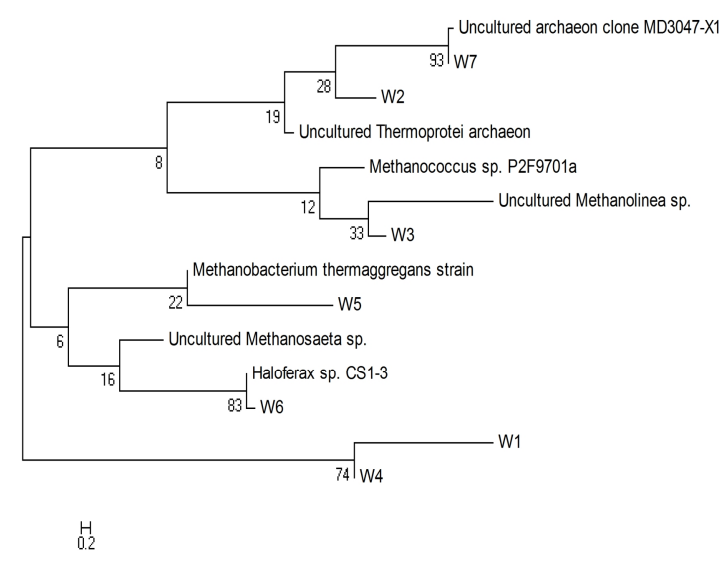

Fig.5 Phylogenetic trees of 16SrDNA gene sequences of archaea before activation and their most similar sequences of GenBank

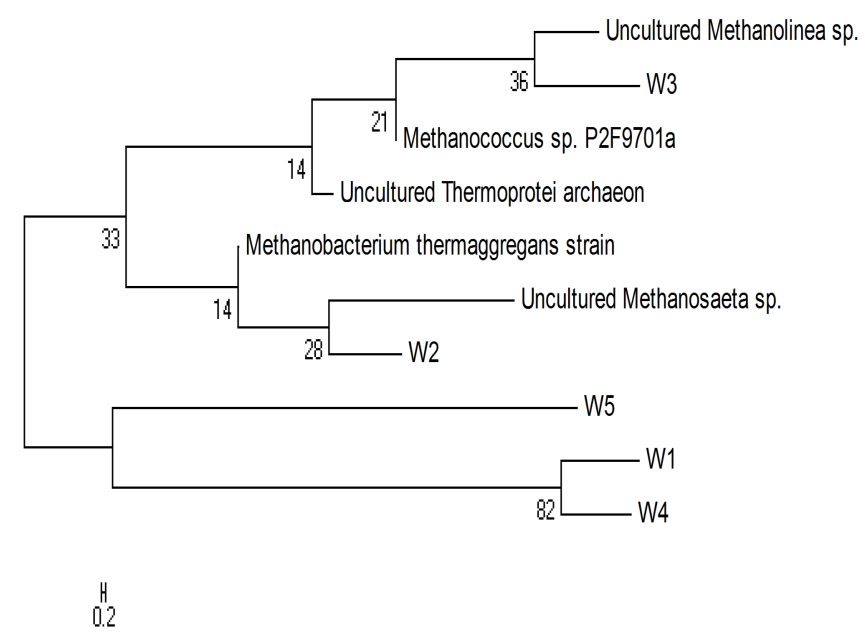

Fig.6 Phylogenetic trees of 16SrDNA gene sequences of archaea after the two nutrient agents' activation and their most similar sequences of GenBank

\section{CONCLUSION}

The second group of nutrient agents has better biogas production performance than the first group. Besides, the oil recovery efficiency of the first and the second group of nutrient agents can be improved by $4.8 \%$ and $3.2 \%$ in physical simulation experiments, respectively. The activated bacteria by the first group of nutrient agents are Pseudomonas sp. and Arcobacter sp.; the activated bacteria by the second group of nutrient agents are Thauera sp., Pseudomonas sp. and uncultured Clostridium sp.. After the two groups of nutrient agents' activation, the major dominant archaea haven't been basically changed. These results showed biogas production of activated bacteria including Thauera sp., Pseudomonas sp. and uncultured Clostridium sp. by the second group of nutrient agents was a key mechanism of indigenous microorganism flooding.

\section{ACKNOWLEDGEMENTS}

This work is supported by Youth Science Fund Project of Heilongjiang Province (No. QC2011094), Doctoral Fund of Daqing Normal University(No. 12ZR06) and Science and Technology Research Program of Heilongjiang Province Office of Education (No.12513005). 
Table 1 Analysis of 16S rDNA gene library of bacteria before activation

\begin{tabular}{ccllcl}
\hline Type & Clone number & $\begin{array}{c}\text { GenBank } \\
\text { Accession number }\end{array}$ & $\begin{array}{c}\text { Phylogenetically closest related organism } \\
\text { phylogenetically identified closest related organism }\end{array}$ & \multicolumn{2}{c}{$\begin{array}{c}\text { Similarity } \\
/ \%\end{array}$} \\
\hline W1 & 56 & AM231040 & Thauera sp. R-24450 & $99 \%$ & activated sludge \\
W2 & 21 & FJ211165 & Pseudomonas sp. IM4 & $99 \%$ & soil \\
W3 & 8 & AY692044 & Uncultured Arcobacter sp. clone I56 & $95 \%$ & reactor \\
W4 & 6 & JF513192 & Acinetobacter baumannii strain MDPSBR172c & $96 \%$ & salt-affected soil \\
W5 & 5 & JQ624314 & Uncultured Bacteroides sp. clone OTU-6-ABB & $97 \%$ & wastewater \\
W6 & 3 & KM494506 & Uncultured Clostridium sp. clone D_33 & $85 \%$ & sample \\
W7 & 1 & KF206381 & Uncultured Marinobacterium sp. clone KSB13 & $99 \%$ & hot springs \\
\hline
\end{tabular}

Table 2 Analysis of $16 \mathrm{~S}$ rDNA gene library of bacteria after activation of the first group of nutrient agents

\begin{tabular}{cccccc}
\hline Type & Clone number & $\begin{array}{c}\text { GenBank } \\
\text { Accession number }\end{array}$ & \multicolumn{2}{c}{$\begin{array}{c}\text { Phylogenetically closest related organism } \\
\text { phylonetically identified closest related organism }\end{array}$} & \multicolumn{2}{c}{$\begin{array}{c}\text { Similarity } \\
/ \%\end{array}$} & Origina \\
\hline W1 & 72 & FJ211165 & Pseudomonas sp. IM4 & $99 \%$ & soil \\
W2 & 18 & DQ234112 & Uncultured Arcobacter sp. clone DS028 & $95 \%$ & mangrove \\
W3 & 6 & AM231040 & Thauera sp. R-24450 & $99 \%$ & activated sludge \\
W4 & 3 & JF513192 & Acinetobacter baumannii strain MDPSBR172c & $96 \%$ & salt-affected soil \\
W5 & 1 & KF206381 & Uncultured Marinobacterium sp. clone KSB13 & $99 \%$ & hot springs \\
\hline
\end{tabular}

Table 3 Analysis of 16S rDNA gene library of bacteria after activation of the second group of nutrient agents

\begin{tabular}{ccllcl}
\hline Type & Clone number & $\begin{array}{c}\text { GenBank } \\
\text { Accession number }\end{array}$ & $\begin{array}{l}\text { Phylogenetically closest related organism } \\
\text { phylogenetically identified closest related organism }\end{array}$ & $\begin{array}{c}\text { Similarity } \\
/ \%\end{array}$ & Origina \\
\hline W1 & 65 & AM231040 & Thauera sp. R-24450 & $99 \%$ & activated sludge \\
W2 & 18 & FJ211165 & Pseudomonas sp. IM4 & $99 \%$ & soil \\
W3 & 13 & KM494506 & Uncultured Clostridium sp. clone D_33 & $85 \%$ & sample \\
W4 & 3 & DQ234112 & Uncultured Arcobacter sp. clone DS028 & $95 \%$ & mangrove \\
W5 & 1 & JF513192 & Acinetobacter baumannii strain MDPSBR172c & $96 \%$ & salt-affected soil \\
\hline
\end{tabular}

Table 4 Analysis of 16S rDNA gene library of archaea before activation

\begin{tabular}{cccccc}
\hline Type & Clone number & $\begin{array}{c}\text { GenBank } \\
\text { Accession number }\end{array}$ & $\begin{array}{c}\text { Phylogenetically closest related organism } \\
\text { phylogenetically identified closest related organism }\end{array}$ & $\begin{array}{c}\text { Similarity } \\
/ \%\end{array}$ & Origina \\
\hline W1 & 54 & KJ877692 & Uncultured Methanosaeta sp. Clone & $98 \%$ & oilfield-produced water \\
W2 & 23 & KF692508 & Uncultured Methanolinea sp. clone & $99 \%$ & oilfield-injected water \\
W3 & 9 & NR_113572 & Methanobacterium thermaggregans strain & $99 \%$ & gas-associated formation water \\
W4 & 7 & AF306670 & Methanococcus sp. P2F9701a & $94 \%$ & estuarine environment \\
W5 & 4 & HM041917 & Uncultured Thermoprotei archaeon clone & $99 \%$ & petroleum reservoir \\
W6 & 2 & GQ478061 & Haloferax sp. CS1-3 & $99 \%$ & salt brine \\
W7 & 1 & KJ131413 & Duganella sp. ZLP-XI & $86 \%$ & pteridophyte rhizosphere soil \\
\hline
\end{tabular}

Table 5 Analysis of 16S rDNA gene library of archaea after activation of the first group of nutrient agents

\begin{tabular}{clllrl}
\multicolumn{3}{c}{ Type Clone number GenBank } & \multicolumn{2}{c}{$\begin{array}{c}\text { Phylogenetically closest related organism } \\
\text { Accession number } \\
\text { phylogenetically identified closest related organism }\end{array}$} \\
\hline W1 & 62 & KJ877692 & Uncultured Methanosaeta sp. clone & $98 \%$ & oilfield-produced water \\
W2 & 25 & KF692508 & Uncultured Methanolinea sp & $99 \%$ & oilfield-injected water \\
W3 & 7 & NR_113572 & Methanobacterium thermaggregans strain DSM 99\% & gas-associated formation water \\
W4 & 6 & AF306670 & Methanococcus sp. P2F9701a & $94 \%$ & estuarine environment \\
W5 & 1 & HM041917 & Uncultured Thermoprotei archaeon clone & $99 \%$ & petroleum reservoir \\
\hline
\end{tabular}


Table 6 Analysis of 16S rDNA gene library of archaea after activation of the second group of nutrient agents

\begin{tabular}{|c|c|c|c|c|c|c|}
\hline \multicolumn{4}{|c|}{ Type Clone number } & \multicolumn{2}{|c|}{$\begin{array}{l}\text { Phylogenetically closest related organism } \\
\text { phylogenetically identified closest related organism }\end{array}$} & $\begin{array}{l}\text { Similarity } \\
\quad 1 \%\end{array}$ \\
\hline W1 & 61 & KJ877692 & Uncultur & ed Methanosaeta sp. clone A141-A1 & $98 \% \quad$ oilfield-produced & \\
\hline W2 & 24 & KF692508 & Uncultu & olinea sp. & oilfield-in & ater \\
\hline W3 & 8 & NR_113572 & Methanc & acterium thermaggregans strain DSM & gas-associatec & mation wate \\
\hline W4 & 6 & AF306670 & Methan & cccus sp. P2F9701a & estuarine envi & iment \\
\hline W5 & 1 & HM041917 & Uncultur & ed Thermoprotei archaeon clone & petroleum rese & rvoir \\
\hline
\end{tabular}

Table 7 The results of indigenous microorganism in the physical simulation flooding experiment

\begin{tabular}{|c|c|c|c|c|c|c|}
\hline Core Number & $\mathrm{k}_{\mathrm{g}} \mathrm{md}$ & $\mathrm{S}_{\mathrm{or}} \%$ & $\mathrm{E}_{\mathrm{w}} \%$ & $0.5 \mathrm{PV}, \mathrm{E}_{\mathrm{p}} \%$ & 0.3 PV Activation System & $\mathrm{E}_{\text {meor }} \%$ \\
\hline 38 & 1006 & 71.8 & 37.6 & 15.7 & $\begin{array}{l}\text { Injected the first activator agents' } \\
\text { system, cultured for } 37 \text { days at } 45^{\circ} \mathrm{C} \text {, } \\
\text { biogas production was observed. }\end{array}$ & 3.4 \\
\hline 47 & 1023 & 65.6 & 48.6 & 8.5 & $\begin{array}{l}\text { Injected the second activator agents' } \\
\text { system, cultured for } 37 \text { days at } 45^{\circ} \mathrm{C} \text {, } \\
\text { biogas production was observed. }\end{array}$ & 4.8 \\
\hline 69 & 1012 & 67.8 & 48.9 & 10.9 & $\begin{array}{l}\text { Injected oil-production water of the } \\
\text { N2-D3-P40 well, cultured for } 37 \text { days } \\
\text { biogas production was observed. }\end{array}$ & 0.8 \\
\hline
\end{tabular}

\section{Reference}

[1] LIU, Y. \& LI, J.L. \& CUI, F.L. 2004. A study of using microorganisms to increase the incrementaloil after polyacrylamides (PAM)flooding. Journal of ShanDong Institute of Light Industry 18 (3):60-62. (in chinese)

[2] ZHANG, X.M. \& SHE,Y.H. \& HUANG, J.F. \& ZHANG, F. \& WANG, J. \& WANG, W.J. \& WANG H.Z. \& Wang, Z.L. 2008. Microbial Diversity of the Daqing Oilfield after Polymer Flooding. Chinese Journal of Applied \& Environmental Biology 14 (5):668-672.(in chinese)

[3] SIEGERT, M. \& SITTE, J. \& GALUSHKO, A. \& KRUGER, M. 2014. Starting up microbial enhanced oil recovery. Adv Biochem Eng Biotechnol 142:1-94.

[4] BELIAEV, S.S. \& BORZENKOV, I.A. \& NAZINA, T.N. \& ROZANOVA, E. P. \& GLUMOV, I. F. \& IBATULLIN, R. R. \& IVANOV, M.V. 2014. Use of microorganisms in the biotechnology for the enhancement of oil recovery. Mikrobiologiia 73(5):687-697.

[5] BAO, M.T. \& KONG, X.P. \& SONG, Y.T. \& CHEN, Y. \& WEI, B. \& ZHANG, S.T. \& WANG, W.D. \& WANG, X.L. 2004. Selective activation condition of stratal microflora of S12 block in Shengli Oilfield. Journal of the University of Petroleum 28(6):44-48. (in chinese)

[6] YANG, Z.Y. \&SHI, M. \& WANG, D.W. \& WANG, J.F. \& DOU, X.M. 2006. Study on authigneous microorganism community distribution and oil recovery mechanism in Daqing Oilfield. Acta Petrolei Sinica 27:95-100. (in chinese)

[7] GONG, X.C. \& LIU, Z.S. \& GUO, P. \& CHI C.Q. \& CHEN, J \& WANG, X.B. \& TANG, Y.Q. \&WU, X.L. \& LIU C.Z. 2012. Bacteria in crude oil survived autoclaving and stimulated differentially by exogenous bacteria. PLoS One 7(9):e40842.

[8] GAO, P. \& Ma, T. \& LIU, R. 2011. Microbial metabolic characteristics and ecological controlling in petroleum reservoir--a review. Wei Sheng Wu Xue Bao 51(6):711-717. (in Chinese)

[9] GUO, L.Y. \& Zhang, Y. Z. \& YANG, N.W. \& BA, Y. \& WANG, H. \& WANG, W.D. 2012. Experiment study on activator optimization of indigenous microorganisms flooding and field tests in Zhan 3 block, Shaojia oilfield. Petroleum Geology and Recovery Efficiency 19(1):79-81. (in Chinese)

[10] LUAN, C.Z. \& DUAN, C.H. \& YUAN, C.Z. \& ZHAO, F.M. 2006. Research of endogenous microorganism flooding in Zhan 3 block. DRI LLING \& PRODUCT ION TECHNOLOGY 
29(2) : 91-93. (in Chinese)

[11] HUANG, Y.H. \& YUAN, H.M. \& WU, X.L. \& SONG, K.P. 2009. Analysis of microbial community structure for the Daqing oil field in low-permeability reservoir block areas. JOURNAL OF DAQING PETROLEUM INSTITUT E 33(4): 63-66. (in Chinese)

[12] REN, G.L. \& QU, L.N. \& LE, J.J. \& YOU, C.M. \& HUANG, Y.H. 2010. Bacterial community structure of Gaotaizi reservoir in Sanan development area in Daqing Oilfield. JOURNAL OF DAQING PETROLEUM INSTITUTE, 35(4):71-76. (in Chinese)

[13] SUN, W. \& ZHANG, F. \& HE, L. \& LI, Z. 2014. Pyrosequencing reveals diverse microbial community associated with the zoanthid Palythoa australiae from the South China Sea. Microb Ecol. 67(4):942-950.

[14] REN, G.L. \& XU, J.X. \& WANG, J. \& ZHANG, H. \& LE, J.J. \& HUANG, Y.H. 2014. Isolation, Identification and Preliminary Performance Evaluation of Pseudomonas aeruginosa Strain. JOURNAL OF NORTHEAST PETROLEUM INSTITUTE 38(4):62-67. (in Chinese) 